important Maya site to be built, namely, Mayapan. One of the objects was to see what light archæology could throw on the considerable post-Conquest literary evidence, it did not resolve every problem, but it meant that we know more about Mayapan than any other Maya site, and that, as the introduction says, this understanding comes nearer to being living history than is true for any other place.

After a valuable introduction by Pollock, the report falls into four parts: (I) "Literary Sources", by Roys; (2) "Civic and Religious Structures", by Proskouriakoff; (3) "Residential and Associated Structures", by Smith; and (4) "Artifacts", by Proskouriakoff. Each section has its own references and its own set of figures, numbered. independently. The pottery is not described, but use is made of a preliminary examination by the late Prof. Brainerd, and a fuller report by R. E. Smith is forecast.

Mayapan differs from the other great Maya sites in that it was a walled city and not primarily a ceremonial centre. It has a relatively minor ceremonial centre as a nucleus, which was probably the first part to be built, and the main temple pyramid seems to have been modelled on the older and much finer Toltec Maya "Castillo" of Chichén Itzá. There were also two circular buildings of the type of the "Caracol" at the same place, but Mayapán differed markedly from its predecessor in its lack of ball courts and signs of the Eagle and Jaguar cults, and in its emphasis on serpents. In its heyday, which lasted from about 1275 until 1450 , it was the capital of a unified Government of Yucatan and is estimated to have contained 11,000-12,000 inhabitants.

There are no surviving buildings of earlier date, but earlier occupations of the neighbourhood are inferred from pre-Classic and Classic pottery, and re-used carved stones. It was built on an area mainly of bare limestone and obtained its food from dependent agricultural provinces, but it had the advantage of a good water supply from a group of 'cenotes' or sink-holes in the limestone. The ruins are not impressive in their decay, owing to the extremely poor quality of the masonry. Buildings were of rough or erudely shaped stones, depending heavily on thick coats of stucco to present a good face, and it is an indication of the decay of the unified religion associa. ted with the old ceremonial centres that the masonry of some chiefs houses was better than that of the few temples. Many house groups had shrines of their own, pointing to the development of a new form of domestic cult, to which may belong also a new form of ornate pottery censer and certain types of idol. House groups were built where possible on natural hillocks on the limestone, and a haphazard grouping was the result. There were few planned roads, and most of the irregular lanes were bounded in a casual fashion by property boundary walls. One interesting feature brought out by the excavations was the predominance of a house type described by Bishop de Landa in the sixteenth century, which was very rare elsewhere and hence almost unknown before, so that the Bishop's accuracy had been unjustly doubted. The general picture is one of decadence, which is borne out by the literary sources, and the life of the city ended in violence.

On some historical matters, particularly the date of arrival of the Itzá at Chichén Itzá, the report reveals a difference of opinion between the historian Roys and the archæologists Thompson and Brainerd. Roys thinks that they arrived in the thirteenth century and remained until about the time of the fall of Mayapán, whereas the archæological view is that it was the Itzá who were responsible for the Toltec Maya work at Chichén during the period c. 980-1200, after which it was abandoned. If this is so, Roys's identification of the Cocom rulers of Mayapán as a branch of the Itzá can scarcely be maintained. All concerned accept the Thompson correlation of the Maya and Christian calendars, although Pollock notes that some radiocarbon dates appear to favour the Spinden correlation. The new and impressive series of measurements from Tikal, which give strong support to the Thompson correlation, was not available soon enough to receive more than a mention in a postscript.

Mayapan proved poor in material remains, but the report is rich in valuable information. The work was well worth doing.

G. H. S. BUSHNELL

\section{A DIRECTORY TO DEVELOPMENT FACILITIES}

Development Guide

A Directory of Development Facilities provided by NonCommercial Organizations in Britain. Pp. 262. (London: George Allen and Unwin, Ltd., 1962.) 25s, net.

A $\mathrm{S}$ technical advances make civilization progressively more complex, the problem of communication becomes increasingly important, and as the realization gains ground that the industrialized countries have a moral obligation to help those parts of the world which are less well developed, the problem of communication is accentuated still further. It was this realization which led to the foundation of the Overseas Development Institute, which is an independent body financed by grants from the Ford and Nuffield Foundations as well as by British industrial and commercial enterprises.

The main object of the Institute is to serve as a centre for the collection, consideration and dissemination of ideas which might foster the material progress of countries in Africa, Latin America and Asia. In pursuit of this object it has now produced a Development Guide. This Guide is a directory of about 200 organizations in Britain which are in a position to take part in assisting areas in need.

Development is not simply a matter of installing a specified amount of industrial plant, for, quite apart from questions of finance, that will have repercussions in other fields, such as the supply of properly qualified staff, transport, postal services, housing, food supplies, health and welfare services, and cultural activities. In the Development Guide this diversity of requirements receives recognition. The first and last entries are Africa Bureau and Young Women's Christian Association of Great Britain; but perhaps more representative of the organizations listed are the Agricultural Research Council, the Association of the Universities of the British Commonwealth, the British Veterinary Association, Political and Economic Planning, the Royal Institute of Chemistry, and the Victoria League for Commonwealth Friendship.

All the organizations mentioned in the Guide are in a position to offer information and advice; many issue specialized publications; some run courses of training which are open to students from overseas, for which scholarships may be available; and several carry out research. The information given on points like these is clear and concise. Reference to educational establishments has been omitted since in their case contacts abroad are maintained by the British Council; at the same time, industrial and commercial concerns are not listed because the services they have to offer are made known through other channels.

The Guide, then, closes a gap in the nation's information services. It will prove useful to a wide range of people in Britzin, who otherwise are not in a position to get a full measure of the range and variety of assistance which is available for devolopment overseas. Still more clearly will it be of value to the countries which are in need, where people must find it very hard to understand how separate projects in development can fit together and reinforce each other, and still more, how they can best set about obtaining aid. R. WEATHERALL 